\title{
Temperatures in the Cothill habitat of Panaxia (Callimorpha) dominula L. (the scarlet tiger moth)
}

\author{
DAVID A. JONES \\ Department of Botany, PO Box 118526, University of Florida, Gainesville, FL 32611-8526, U.S.A.
}

\begin{abstract}
Temperatures were monitored in precisely the places in Cothill Fen in which larvae of Panaxia dominula pupate. At the critical time in June, the temperatures in the litter layer are diurnally often much higher than those used in previous constant temperature experiments. Moreover, the daily mean temperature in the shaded litter layer is also higher than the shaded air temperature at $0.4 \mathrm{~m}$, both temperatures being higher than the estimate of $12^{\circ} \mathrm{C}$ used as baseline by others. The effects of fluctuating temperatures in the natural habitat on the phenotypic expression of wing patterns of the moth appear to be minimal and do not parallel the results of laboratory experiments.
\end{abstract}

Keywords: genetic polymorphism, medionigra, Panaxia (Callimorpha) dominula, temperature.

\section{Introduction}

The study of the medionigra form of the moth Panaxia (Callimorpha) dominula L. in the colony at Cothill, Oxfordshire, England, begun in 1939, has continued to provide controversy in interpretation (Clarke et al., 1993a,b, 1996; Cook, 1993; Jones, 1993a,b; Owen \& Clarke, 1993; Owen \& Goulson, 1994; Cook \& Jones, 1996; Goulson \& Owen, 1997; Goulson, 1999; Jones \& Cook, 1999). Following Kettlewell (1943/44), Owen \& Clarke (1993) predicted that temperature could affect the expression of the medionigra phenotype. Owen \& Goulson (1994) and Goulson \& Owen (1997) demonstrated an increase in the proportion of individuals they scored as medionigra when late larvae and pupae were raised at constant temperatures.

A reanalysis of the field data by Cook \& Jones (1996) was based on the published mean temperatures for June in central England. June was chosen because most of the larvae pupate in that month. No effect of temperature on the frequency of medionigra was detectable. They commented, however, that 'the temperature actually experienced by the insects may be controlled by their choice of pupation site'.

In a brood containing medionigra Kettlewell (1943/ 44) observed an increase in the number of black scales in the critical regions of the wings, particularly of the hind wings, when pupae were subjected to a 'constant' $21^{\circ} \mathrm{C}$ throughout their development, whereas pupae

Correspondence. E-mail: djones@botany.ufl.edu from the same brood raised 'at varying out-of-doors temperature(s)' showed no such increase. Owen \& Goulson (1994) repeated these experiments using constant temperatures of $12^{\circ}, 18^{\circ}$ and $24^{\circ} \mathrm{C}$ on larvae and pupae from two colonies (Cothill and North Hinksey, Oxfordshire). They used the frequencies of medionigra among wild-caught adults of the same cohort (1993) from the two colonies for comparison. The $12^{\circ} \mathrm{C}$ temperature was thought to be about the same as the mean air temperature in the wild' (Owen \& Goulson, 1994) and so could be regarded as the baseline for comparisons. Although all three treatments increased the proportion of individuals scored as medionigra over wild controls, $18^{\circ} \mathrm{C}$ apparently had little effect on insects from Cothill and an intermediate effect on the sample from North Hinksey. This apparent anomaly was not explained.

In a follow-up experiment (Goulson \& Owen, 1997), larvae and pupae from another habitat (Axmouth, Devon) were subjected to $18^{\circ} \mathrm{C}$ and $24^{\circ} \mathrm{C}$, but not to $12^{\circ} \mathrm{C}$, and compared with the earlier experiments and with moths from a Deal, Kent, population held in the British Museum, Natural History. Again they reported an increase in the frequency of insects they scored as medionigra among the adults.

All previous discussions of temperature in the environment of $P$. dominula have been confined to air temperatures, often meteorological records from some distance away (Kettlewell, 1943/44; Owen \& Clarke, 1993; Owen \& Goulson, 1994; Clarke et al., 1996; Cook \& Jones, 1996; Goulson \& Owen, 1997), but the larvae 
pupate under the litter at ground level from late May and not in midair. Thus it is necessary to measure the actual temperatures to which late larvae and pupae are subjected in their natural habitat.

I report the results of measuring temperatures in the Cothill habitat. I also update to 1999 the annual fieldwork data from which the population size and the frequency of the medionigra allele can be estimated.

\section{Methods}

Cothill Fen (Parsonage Moor) is an alkaline fen fed by a number of small streams. There is much evidence of earlier peat cutting, but the remaining uncut areas are thick with plant debris at various stages of decomposition. Currently the dominant species surrounding the major food plant of $P$. dominula (Symphytum officinale L.) are Phragmites australis (Cav.) Trin. ex Steudel, Eupatorium cannabinum L. and Filipendula ulmaria (L.) Maxim., the last two also being food plants for the moth. The last three are tall plants in this habitat. It is very unlikely that any direct sunlight reaches the level of the litter in the fen after late May.

Temperatures were measured with $\mathrm{Hobo}^{\circledR}$ XT temperature loggers (the square box type, -5.0 to $+37^{\circ} \mathrm{C}$ range, Onset Computer Corporation) attached by short cables to external thermistor probes. The covers of the thermistors happened to be the same length and colour as $P$. dominula pupae although somewhat narrower. The data loggers were placed in round $235 \mathrm{~mL}$ plastic food containers (Rubbermaid ${ }^{\circledR}$ ) each with a hole in the side through which the cable was passed. All was sealed with exterior grade window sealant. Each container was protected by a $1-\mathrm{m}$ long, $115-\mathrm{mm}$ diameter drainage pipe pushed vertically into the soil. The thermistor and cable were passed through a small hole made in the drainpipe at ground level, below the loose litter. The thermistors were placed in plant litter under or near to the canopy of Symphytum officinale plants, up to $1 \mathrm{~m}$ from the crown of a plant. The larvae scatter from the food plant to pupate in nature (Kettlewell, 1942/43; Sheppard, 1951; D.A.J., pers. obs.), whereas in captivity they often have no choice but to pupate in the food plant (Porter, 1997; D.A.J., pers. obs.).

As a trial, two loggers were placed at different sites within Cothill fen in late July 1995 and the data downloaded into a computer in mid-December 1995. The cables of both probes had been damaged by rodents in November and thus the sequences of data were incomplete for that period.

The loggers were replaced in the field in late December 1995 fitted with new thermistor probes. Fine metal tubing covered the cables. A clear plastic $35 \mathrm{~mm}$ photographic film canister (Fuji) was attached by sealant to the end of each tube. Numerous holes were punched through the wall of the canister using a fine soldering iron. Each thermistor probe was adjusted to be approximately $15 \mathrm{~mm}$ beyond the end of the tube, hanging free within the canister. The tubes and canisters were covered by moss and litter typical of the area, care being taken to ensure that the thermistors and their cables would not be exposed to direct sunlight at any time of the year.

In the field, full sets of data were downloaded from the two loggers in late June 1996 (see Table 1). The data loggers were reset and returned to the field. At the end of July the loggers were collected and replaced by new ones. During a management activity in the fen, there had been extensive clearance of shrubs and trees in the spring of 1996. As a result a new site (North-east) was chosen for the second data logger (Table 1). Furthermore, the clearance work had reopened parts of the fen to the moth and an additional site for collecting temperature data was later chosen in the North-west of the fen (Table 1).

The calibration of each logger and thermistor probe was subsequently checked in the laboratory by standard methods. It was also necessary to justify that the Fuji film canisters were not distorting the readings. Pairs of Hobos were set up as described above and placed in constant temperature $\left(18^{\circ} \mathrm{C}\right)$ and fluctuating temperature $\left(7-22^{\circ} \mathrm{C}\right)$ incubators. The probe of one of each pair was exposed, and the other was contained within a Fuji canister. After a few days the canister was transferred to the other probe of each pair. The two sets of readings from each incubator matched almost exactly.

In April 1997 it was possible to begin measuring air temperatures. A Stevenson Screen or similar device could not be used, because security was likely to be a problem. Hobo XT loggers with a temperature recording range of -37 to $+46^{\circ} \mathrm{C}$ were chosen. They were sealed into round plastic food containers as before. The containers were mounted on marine grade plywood boards and protected both by plywood screens and by chicken wire. The thermistors were positioned $0.4 \mathrm{~m}$ above ground level in such a way that they would not be exposed to direct sunlight or to rain. Two devices were placed in the fen with regard both to their security and to the appropriateness of the data they would collect, because their data would be the controls for comparison with those obtained from the litter-level Hobos (Table 1).

Sets of data were collected at the end of June and again at the end of July. A cycle of setting up loggers and downloading data was repeated so that relevant data were retrieved in July of 1998 and 1999. The performance of each Hobo and thermistor probe was checked both before being placed in the field and immediately after the data had been downloaded. 


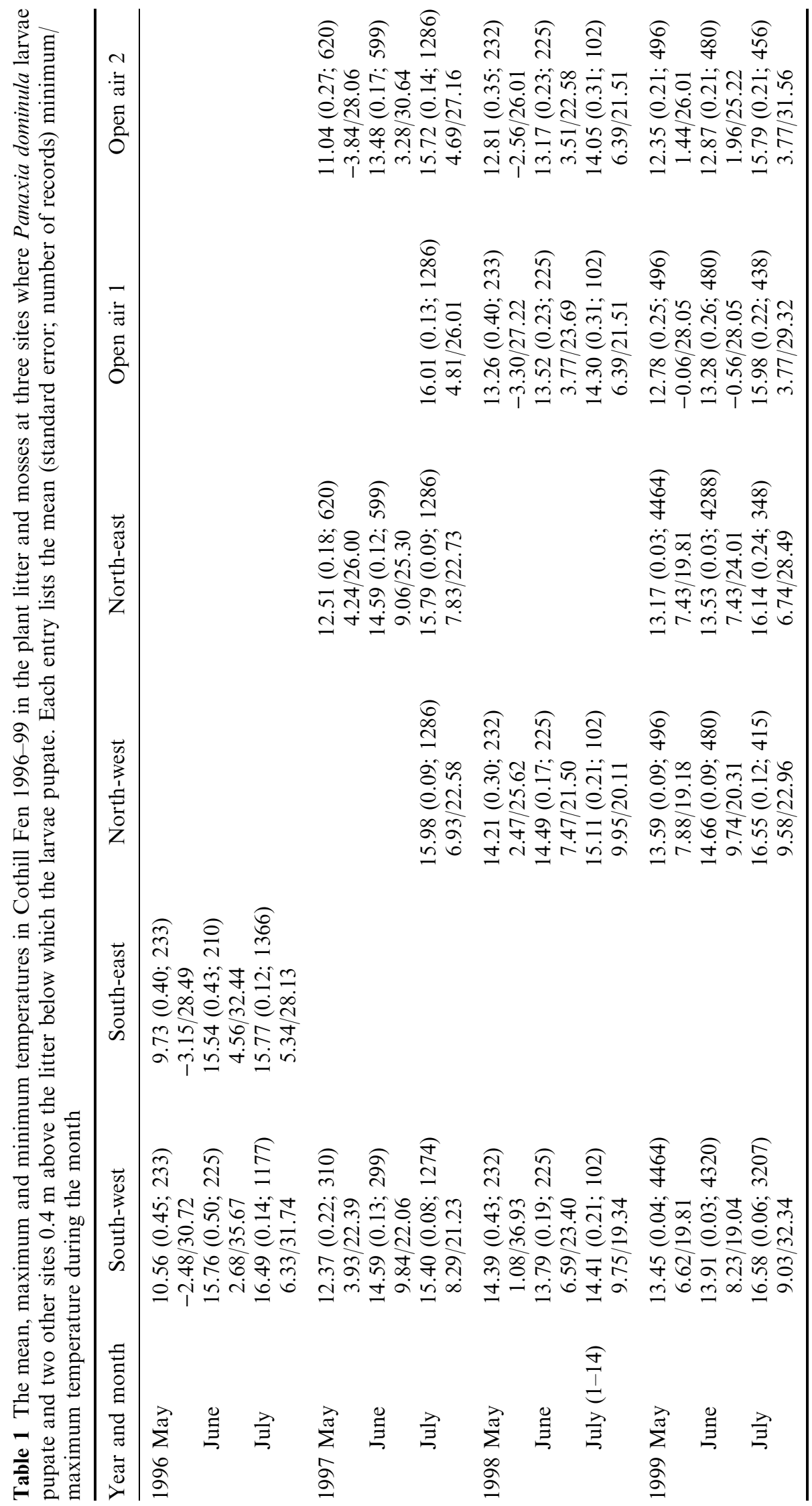

(c) The Genetical Society of Great Britain, Heredity, 84, 578-586. 
The initial processing of the data used the LOGBOOK program that came with the data loggers. The data were transferred for statistical analysis by appropriate programs in Sigma Stat ${ }^{\circledR}$. Because the temperature data were not normally distributed they were analysed by nonparametric methods.

The moths were sampled in July in 1996 to 1999 (inclusive) using the traditional technique for this work of mark-release-recapture and catch-per-unit-effort originating in Fisher \& Ford (1947). The results of subsequent sampling can be found in Sheppard (1951), Sheppard \& Cook (1962), Ford \& Sheppard (1969), Lees (1970), Ford (1975, 1981) and Jones (1993b).

\section{Results}

The monthly maximum, minimum and mean temperatures over the relevant time periods are given in Table 1. Tables 2 and 3 contain the latest mark-release-recapture data presented in the same format as earlier (Jones, 1993b; Cook \& Jones, 1996). Figure 1(a,b) shows the patterns of temperature over the critical period from late May to early July 1998 at the South-west site and at one of the air temperature sites. Figure $2(a-d)$ shows the daily mean temperatures for June in 1996-99.

Of the original captures of $P$. dominula in 1996, 1997 and 1998, none could be classified as 'classical' medionigra (columns $\mathrm{g}$, $\mathrm{h}$ and $\mathrm{i}$ in Table 2; see Jones, 1993b for the rationale for this statement), but 10 were scored as 'yellow spot' medionigra in 1996 (columns e and f in
Table 2), 17 in 1997, and five in 1998. In 1999, however, three individuals were scored as classical medionigra, with a further eight being yellow spot medionigra. Thus, the overall frequencies of medionigra for the years 1996 99 were $3.01,3.74,1.21 \%$ and $2.63 \%$, respectively (Table 3). These frequencies were lower than for 1993, the year that Owen \& Goulson (1994) used as the control for their constant temperature experiments.

\section{Discussion}

\section{The temperature measurements}

Apart from the damage caused by rodents in November 1995 (the Hobos recorded the date and time!) there has been no evidence of tampering with any of the equipment over a four-year period. At different times, four of the loggers failed to provide full sets of data (hence some of the gaps in Table 1), but this was essentially the result of user error and not a fault of the Hobos themselves.

Unfortunately, there are no data for air temperatures at Cothill during the summer of 1996, but the patterns of the pairs of litter and air temperature data for each of the years 1997, 1998 and 1999 appear to be comparable. For example, the traces for 1998 are shown in Fig. 1(a,b). During a 24-h period we should expect the maximum and minimum temperatures in the air to be more extreme than in the litter layer, essentially because the litter will dampen both heat loss to the air and heat

Table 2 Forewing median spots and hind wing spots in Panaxia dominula at Cothill 1988-99. Columns $\mathrm{h}$ and i are classical medionigra, e and $\mathrm{f}$ are yellow spot medionigra and are included as medionigra in Table 3. Moths from column $\mathrm{g}$ were scored as medionigra. See Jones (1993b) for an explanation for this scoring

\begin{tabular}{|c|c|c|c|c|c|c|c|c|c|c|}
\hline $\begin{array}{l}\text { Forewing } \\
\text { median spot }\end{array}$ & $\begin{array}{c}\mathrm{a} \\
\text { Normal }\end{array}$ & $\begin{array}{c}\mathrm{b} \\
\text { Reduced }\end{array}$ & $\begin{array}{c}\mathrm{c} \\
\text { Absent }\end{array}$ & $\begin{array}{c}\mathrm{d} \\
\text { Normal }\end{array}$ & $\begin{array}{c}\mathrm{e} \\
\text { Reduced }\end{array}$ & $\begin{array}{c}\mathrm{f} \\
\text { Absent }\end{array}$ & $\underset{\text { Normal }}{\mathrm{g}}$ & $\begin{array}{c}\mathrm{h} \\
\text { Reduced }\end{array}$ & $\begin{array}{c}\mathrm{i} \\
\text { Absent }\end{array}$ & \\
\hline Hindwing & red & red & red & $\begin{array}{c}\text { yellow } \\
\text { spot }\end{array}$ & $\begin{array}{c}\text { yellow } \\
\text { spot }\end{array}$ & $\begin{array}{c}\text { yellow } \\
\text { spot }\end{array}$ & $\begin{array}{l}\text { black } \\
\text { spot }\end{array}$ & $\begin{array}{l}\text { black } \\
\text { spot }\end{array}$ & $\begin{array}{l}\text { black } \\
\text { spot }\end{array}$ & Total \\
\hline 1988 & 611 & —* & —* & 5 & 2 & 0 & 0 & 2 & 2 & 622 \\
\hline 1989 & 759 & 14 & 0 & 25 & 9 & 0 & 4 & 4 & 2 & 817 \\
\hline 1990 & 491 & 10 & 0 & 17 & 2 & 0 & 0 & 3 & 2 & 525 \\
\hline 1991 & 1975 & 42 & 0 & 15 & 15 & 1 & 0 & 11 & 7 & 2066 \\
\hline 1992 & 1983 & 238 & 0 & 24 & 31 & 0 & 0 & 12 & 2 & 2290 \\
\hline 1993 & 327 & 125 & 0 & 8 & 19 & 0 & 0 & 4 & 0 & 483 \\
\hline 1994 & 106 & 104 & 0 & 8 & 6 & 0 & 0 & 2 & 0 & 226 \\
\hline 1995 & 90 & 41 & 0 & 3 & 7 & 0 & 0 & 1 & 0 & 142 \\
\hline 1996 & 238 & 73 & 0 & 11 & 10 & 0 & 0 & 0 & 0 & 332 \\
\hline 1997 & 305 & 123 & 0 & 10 & 17 & 0 & 0 & 0 & 0 & 455 \\
\hline 1998 & 324 & 82 & 0 & 3 & 5 & 0 & 0 & 0 & 0 & 414 \\
\hline 1999 & 348 & 48 & 0 & 12 & 8 & 0 & 0 & 3 & 0 & 419 \\
\hline Totals & 7556 & 901 & 0 & 141 & 131 & 1 & 4 & 42 & 15 & 8791 \\
\hline
\end{tabular}

*Not scored in 1988

(C) The Genetical Society of Great Britain, Heredity, 84, 578-586. 


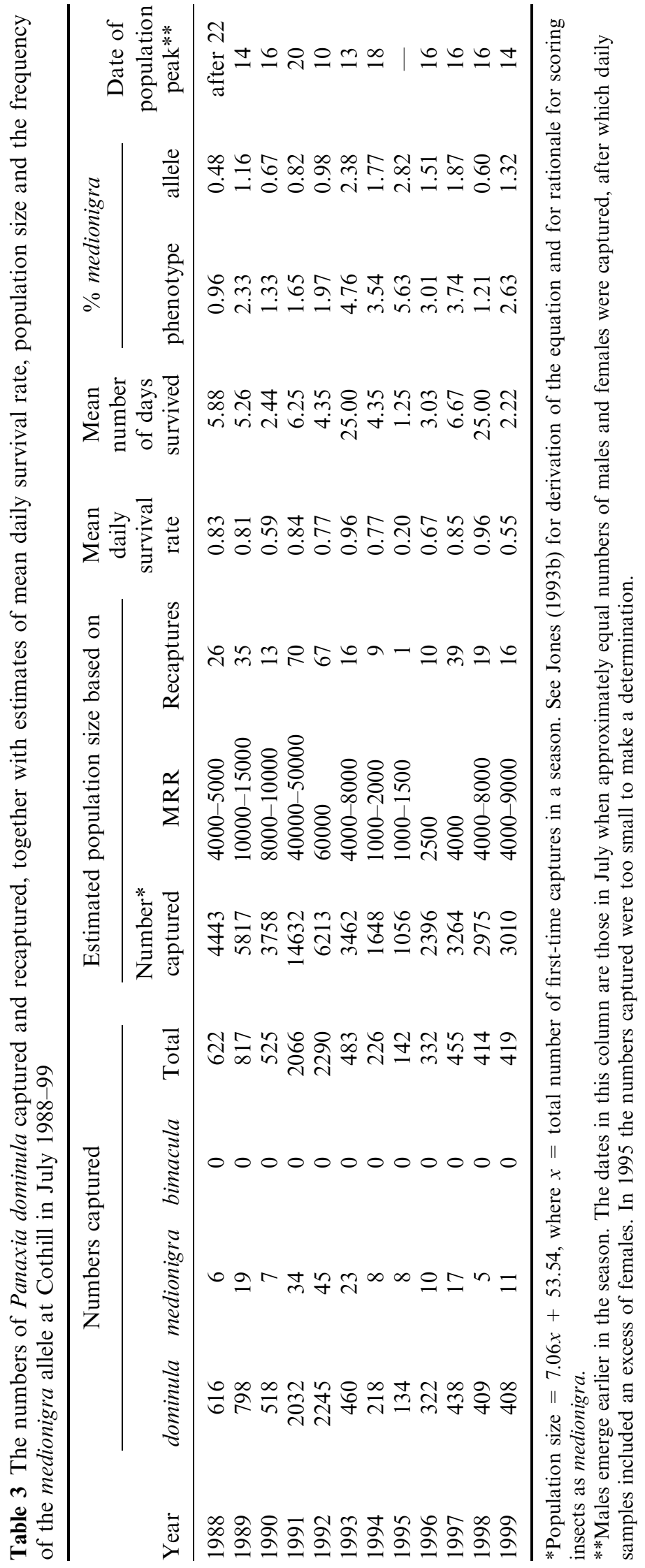

(c) The Genetical Society of Great Britain, Heredity, 84, 578-586. 
Fig. 1 (a) Pattern of diurnal temperature from 21 May to 10 July 1998 at the South-west site. Temperature was measured under the surface litter in precisely the places where Panaxia dominula larvae pupate. (b) Pattern of diurnal temperature from 21 May through 10 July 1998 at $0.4 \mathrm{~m}$ above the litter below which $P$. dominula larvae pupate.
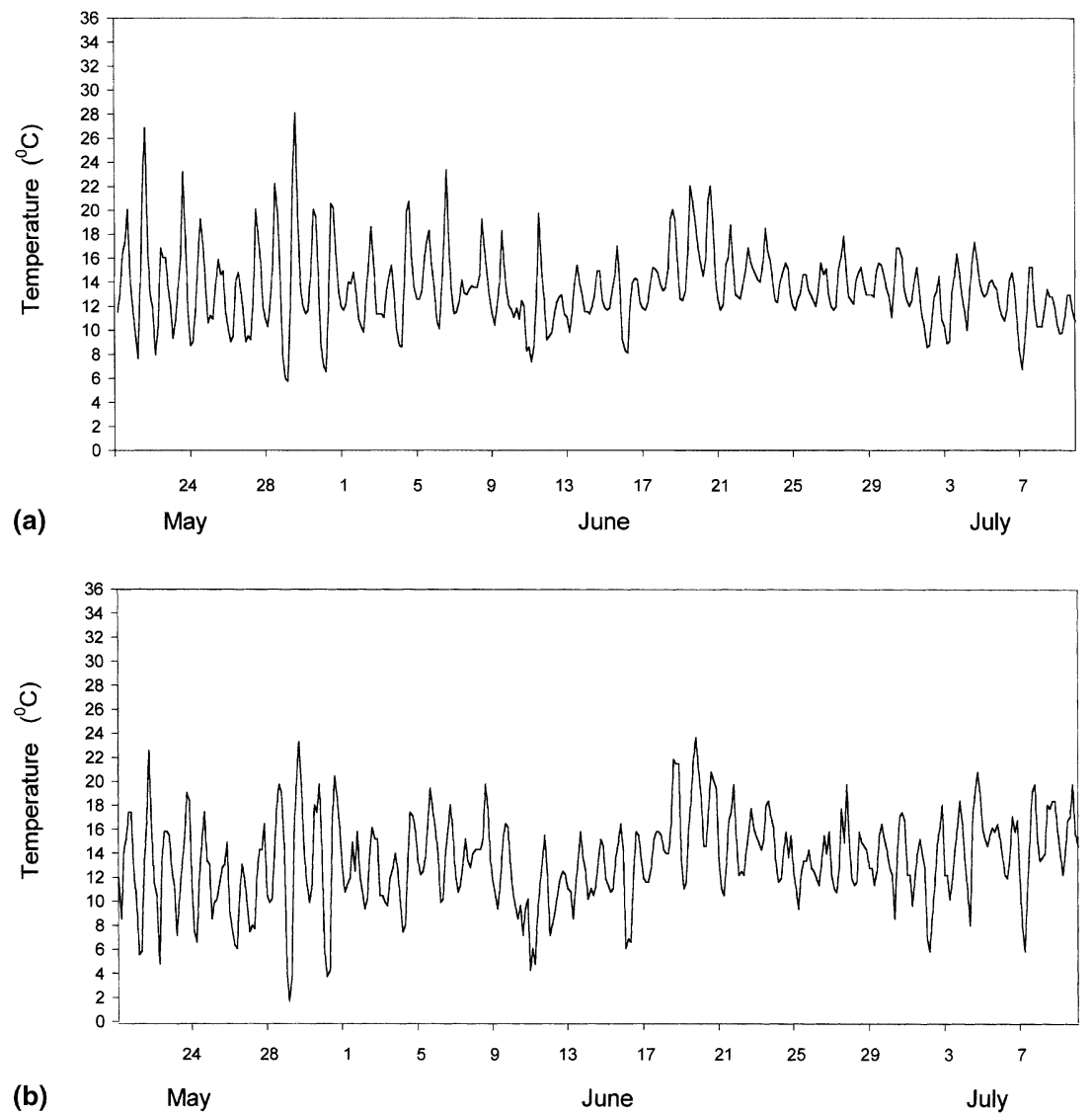

gain from it. The data in Fig. 1(a,b) show that this is generally true for the minimum temperature, but not for the maximum. This suggests that there is either heat retention or heat generation in the litter.

There are two independent pieces of evidence to suggest that the litter layer is being heated from a source other than from the air or direct sunlight. First, in 21 of the 22 possible comparisons (Table 1) the mean temperatures for May, June and July in the litter sites are higher than the corresponding mean air temperatures. The exception is at the South-west site in July 1997. Secondly, when the maximum air temperature on a given day is near the monthly mean the litter temperature is very similar. This is emphasized by the data in Table 4. There were five days in June 1997 and two in 1998 (none in 1999) when the maximum air temperature was lower than the monthly average air temperature. On all seven occasions the corresponding maximum day temperature in the litter was higher than the air temperature. It appears, therefore, that the temperature within the litter is higher than should be expected on a cold day in early summer. Because the vegetation is already sufficiently tall to prevent radiant energy from reaching the litter directly, the only possible source of the extra heat is from the composting of decaying vegetation below the litter. The temperature at the pupation sites may be higher therefore than it would be if there were no decomposing litter.

\section{Raised and lowered constant temperature and the medionigra phenotype}

Raised temperature The original objective in Kettlewell $(1943 / 44)$ was to speed up the life cycle of $P$. dominula by raising a number of broods at $21^{\circ} \mathrm{C}$, a higher temperature than the insects would experience in the wild. This objective was achieved, but he reported accentuated expression of medionigra in the one brood that contained the medionigra allele and darkening of the wings of insects in another brood that did not include the medionigra allele. With the rest of the broods (he did not say how many broods were tested) the only noted effects of temperature on the moths were with the apical spots. These spots are not important in determining the medionigra phenotype. He concluded that the absence of temperatures below $21^{\circ} \mathrm{C}$ might have been responsible for the darkening effects. Except for July 1998 and May and June 1999, the maximum temperatures at 

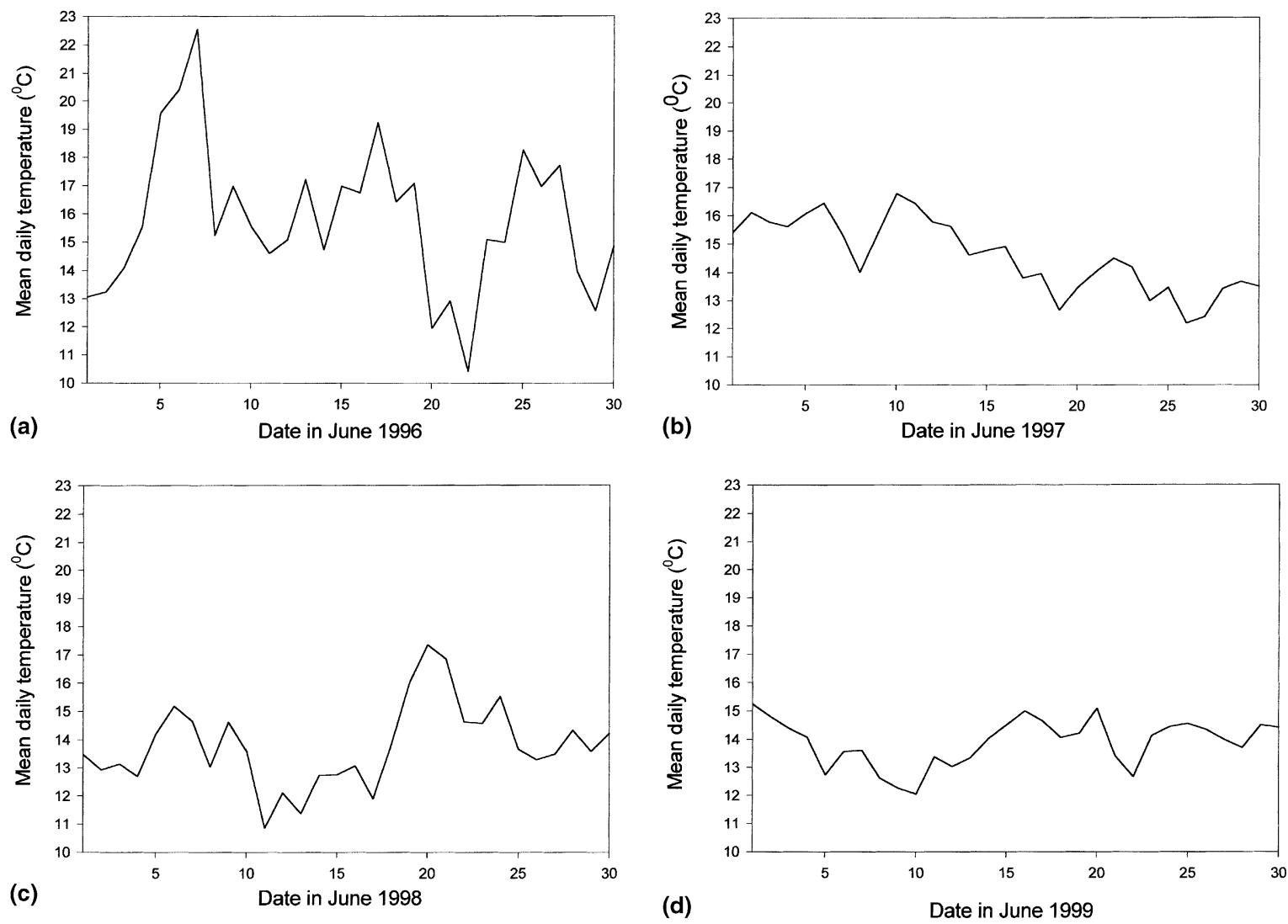

Fig. 2 Daily mean temperatures at the South-west site during June: (a) 1996; (b) 1997; (c) 1998; (d) 1999.

Table 4 Maximum temperature $\left({ }^{\circ} \mathrm{C}\right)$ at the South-west site for days when the maximum air temperature was less than the monthly mean air temperature

\begin{tabular}{|c|c|c|c|c|c|c|c|c|c|}
\hline \multirow[b]{2}{*}{$\begin{array}{l}\text { Maximum day } \\
\text { temperature }\end{array}$} & \multicolumn{6}{|c|}{ Date in June 1997} & \multicolumn{3}{|c|}{ Date in June 1998} \\
\hline & 18 & 19 & 25 & 26 & 27 & $\begin{array}{l}\text { Monthly } \\
\text { mean }\end{array}$ & 11 & 26 & $\begin{array}{c}\text { Monthly } \\
\text { mean }\end{array}$ \\
\hline Open air & 13.36 & 12.58 & 12.58 & 10.88 & 13.05 & 13.48 & 9.37 & 13.12 & 13.17 \\
\hline South-west site & 14.49 & 13.40 & 13.56 & 12.32 & 13.25 & 14.59 & 12.47 & 14.64 & 13.79 \\
\hline
\end{tabular}

In June 1996 and June 1999 no days fitted the criteria.

Cothill in May, June and July of 1996-99 were all in excess of $21^{\circ} \mathrm{C}$. Thus the larvae and pupae do experience temperatures higher than those used in Kettlewell's experiments.

Lowered temperature Owen \& Goulson (1994) wrote interestingly, the experiments responded to the $12^{\circ} \mathrm{C}$ treatment, even though this is about the same as the mean air temperature in the wild.' Presumably $12^{\circ} \mathrm{C}$ is what they had regarded as the baseline temperature that would produce the average phenotype. The observations in Table 1 show mean air temperatures in June higher than $12^{\circ} \mathrm{C}$ by $1.5^{\circ} \mathrm{C}, 1.34^{\circ} \mathrm{C}$ (mean) and by $1.1^{\circ} \mathrm{C}$ in 1997/98/99, respectively. Although these are not large temperature differences, the average differences in pupating temperature were $3.7^{\circ} \mathrm{C}, 2.6^{\circ} \mathrm{C}, 2.1^{\circ} \mathrm{C}$ and $2.0^{\circ} \mathrm{C}$, respectively, in the four years 1996-99. To a human with a fever such small temperature changes can make the difference between life and death. Perhaps even small changes in average temperatures above $12^{\circ} \mathrm{C}$ or below $24^{\circ} \mathrm{C}$ can reduce the darkening effect. Jones \& Cook (1999) have argued, on the contrary, that the wing 
pattern development of medionigra could be disrupted at either end of the temperature range, but is relatively stable inbetween. They suggested that this is exactly what we should expect following the evolution of recessivity of medionigra.

Constant raised temperatures Owen \& Goulson (1994) suggest that a medionigra phenotype would be induced by exposure either to a high temperature or to a stable temperature regime. It is puzzling that neither Owen \& Goulson (1994) nor Goulson \& Owen (1997) reported the results of experiments at fluctuating temperatures or commented beyond the quotation above about the role of $12^{\circ} \mathrm{C}$ in determining the phenotype.

The experiments by Kettlewell and by Owen and Goulson were based on constant temperatures. Stable temperature regimes do not exist in the natural habitat of the moth (Figs 1 and 2; Table 1), although the composting effect does buffer the temperatures at the low end. Table 1 shows that the temperatures experienced by pupae diurnally at Cothill are sometimes in excess of $24^{\circ} \mathrm{C}$. For better comparisons between years, the daily mean temperatures in June at the South-west site are presented, on the same scale, in Fig. 2(a-d) and the number of days during June in which the temperature exceeded 18,21 or $24^{\circ} \mathrm{C}$ is shown in Table 5. Clearly the patterns of temperature vary between years. In 1996 the daily means fluctuated violently and 23 days had temperatures over $21^{\circ} \mathrm{C}$. 1997 shows a steady decline during the month, with only one day with a temperature over $21^{\circ} \mathrm{C}$ and yet that year showed the highest frequency of medionigra of the four years under discussion. Only two days in June 1998 had temperatures over $21{ }^{\circ} \mathrm{C}$. There are some days hotter and some colder in 1998 than in either 1997 or 1999, but not as extreme as in 1996. However, 1998 saw the lowest medionigra frequency of all four years. The pattern of the mean temperature in June 1999 is the most stable observed to date. Only two days had temperatures exceeding $18^{\circ} \mathrm{C}$. Furthermore, the difference between the maximum and minimum temperatures at any time during the month was less than $11^{\circ} \mathrm{C}$, whereas the ranges in $1996-98$ were $33.0,12.2$ and $16.8^{\circ} \mathrm{C}$, respect-

Table 5 Number of days and hours per day when the temperature at the South-west site exceeded 18, 21 and $24^{\circ} \mathrm{C}$, respectively

\begin{tabular}{cccccc}
\hline Year & $>7.5 \mathrm{~h}$ & $5-7.5 \mathrm{~h}$ & $2.5-5 \mathrm{~h}$ & $<2.5 \mathrm{~h}$ & Total \\
\hline 1996 & $20 / 15 / 0$ & $3 / 5 / 6$ & $1 / 3 / 9$ & $0 / 0 / 4$ & $24 / 23 / 19$ \\
1997 & $0 / 0 / 0$ & $5 / 0 / 0$ & $2 / 1 / 0$ & $2 / 0 / 0$ & $9 / 1 / 0$ \\
1998 & $0 / 0 / 0$ & $3 / 0 / 0$ & $3 / 0 / 0$ & $7 / 2 / 0$ & $13 / 2 / 0$ \\
1999 & $0 / 0 / 0$ & $0 / 0 / 0$ & $2 / 0 / 0$ & $0 / 0 / 0$ & $2 / 0 / 0$ \\
\hline
\end{tabular}

ively. The closest natural situation to the laboratory experimental conditions occurred therefore in 1999; three individuals scored as classical medionigra were caught, the first since 1995, but the overall frequency of medionigra did not exceed that observed in 'unfavourable' years. Thus, the relatively stable temperature regime in June 1999 does not appear to have increased the frequency of medionigra in the natural population.

Although the patterns of temperature in June of the four years were very variable, the patterns of emergence of the adults were not (Table 6). At the beginning of the flying season more males are captured than females. At peak emergence the numbers are equal. This is followed by an increase in the proportion of females in the daily captures. Table 6 shows that the peak emergence was the same date in July in three of the four years and two days earlier in 1999. By comparison, the equivalent dates for earlier years (Table 3) show a range from the 10 th to 20th July. In two extreme years the relevant dates were 30th July (1958 and 1972). The numbers of medionigra captured before the peak emergence date in 1996 through 1999 are very similar to numbers after that date. Thus in spite of the great differences in the patterns of temperatures between the four years there appears to have been no effect on the time of emergence of medionigra.

We have to conclude, therefore, that the effect of constant elevated temperatures in the laboratory, although revealing the potential with respect to phenotypic expression, remains a laboratory phenomenon and of little or no relevance to the situation with $P$. dominula at Cothill.

Inevitably some individual larvae and pupae would be subjected to different temperature regimes than others, even though the litter layer acts as an effective blanket. Clearly, if temperature were an important influence on the phenotypic expression of medionigra at Cothill, we would expect any such effect on the frequency of medionigra be more marked in a year with high June temperatures than in an average year. The insects would mature earlier, there should be an increase in the frequency of medionigra and there should be a bias

Table 6 Numbers of medionigra scored before and after the date on which the sex ratio changed from excess of males to excess of females

\begin{tabular}{lcc}
\hline Date & Before & After \\
\hline 16 July 1996 & 4 & 6 \\
16 July 1997 & 7.5 & 9.5 \\
16 July 1998 & 4 & 1 \\
14 July 1999 & 6.5 & 4.5 \\
\hline
\end{tabular}


towards medionigra in the first half of the season. There is no evidence of any such effects in 1996.

The maximum and minimum daily temperatures and the monthly average temperatures have been measured at the time and site of pupation and metamorphosis of $P$. dominula. These field observations show that the frequency of medionigra and the temperatures measured both at the sites of pupation and in air near the ground in Cothill Fen are unrelated. Thus the laboratory experiments have been misleading and do not help to explain the decline and annual fluctuations in the frequency of medionigra in the Cothill population of P. dominula.

\section{Acknowledgements}

I am grateful to Laurence Cook, Feo and Cyril Clarke, Lincoln Brower, David Lees and Denis Owen for discussions about the problems with Panaxia dominula.

\section{References}

ClARKe, C. A., ClARKe, F. M. M. AND OWEN, D. F. 1993a. Gene frequencies in an artificial Wirral colony of the scarlet tiger moth, (Panaxia dominula L.) in the four years after its rediscovery: 1989-92. The Linnean, 9, 18-20.

ClARKE, C. A., OWEN, D. F. AND ClARKE, F. M. M. 1993b. Letter to the editors. The Linnean, 9, 18-21.

ClARKE, C. A., ClARKE, F. M. M. AND MACDONALD, W. W. 1996. New observations on the experimental colony of the scarlet tiger moth (Panaxia dominula) on the Wirral Way, West Kirby, Merseyside. The Linnean, 11, 14-19.

COOK, L. M. 1993. Letter to the editors. The Linnean, 9, 14-16. COOK, L. M. AND JONES, D. A. 1996. The medionigra gene in the moth Panaxia dominula: the case for selection. Phil. Trans. R. Soc. B, 351, 1623-1634.

FISHER, R. A. AND FORD, E. B. 1947. The spread of a gene in natural conditions in a colony of the moth Panaxia dominula L. Heredity, 1, 143-174.

FORD, E. B. 1975. Ecological Genetics, 4th edn. Chapman \& Hall, London.
FORD, E. B. 1981. Taking Genetics Into the Countryside. Weidenfeld and Nicolson, London.

FORD, E. B. AND SHEPPARD, P. M. 1969. The medionigra polymorphism of Panaxia dominula. Heredity, 24, 561569.

GOULSON, D. 1999. Why studies of the medionigra polymorphism in Panaxia dominula do not provide evidence for natural selection. Oikos, 87, 181-182.

GOULSON, D. AND OWEN, D. F. 1997. Long-term studies of the medionigra polymorphism in the moth Panaxia dominula: a critique. Oikos, 80, 613-617.

JONES, D. A. 1993a. Letter to the editors. The Linnean, 9, 17-18. JONES, D. A. 1993b. The phenotype and frequency of f. medionigra of Panaxia dominula L. (Lepidoptera: Arctiidae) at Cothill, Oxfordshire, England. 1988-91. Biol. J. Linn. Soc., 49, 305-316.

JONES, D. A. AND COOK, L. M. 1999. Temperature effects and the medionigra phenotype of Panaxia dominula. Comments on Owen and Goulson (1994) and Goulson and Owen (1997). Oikos, 87, 175-180.

KetTlewell, H. B. D. 1942/43. A survey of the insect Panaxia (Callimorpha) dominula, L. Proc. South London Entomol. Nat. Hist. Soc., 1943/44, 1-49.

KETTLEWELL, H. B. D. 1943/44. Temperature experiments on the pupae of (1) Heliothis peltigera Schiff. and (2) Panaxia dominula Linn. Proc. South London Entomol. Nat. Hist. Soc., 1943/44, 69-83.

LEES, D. R. 1970. The medionigra polymorphism of Panaxia dominula in 1969. Heredity, 25, 470-475.

OWEN, D. F. AND CLARKE, C. A. 1993. The medionigra polymorphism in the moth Panaxia dominula (Lepidoptera: Arctiidae): a critical re-assessment. Oikos, 67, 393-402.

OWEN, D. F. AND GOULSON, D. 1994. Effect of temperature on the expression of the medionigra phenotype of the moth Panaxia dominula (Lepidoptera: Arctiidae). Oikos, 71, 107-110.

PORTER, J. 1997. The Colour Identification Guide to Caterpillars of the British Isles. Viking, Harmondsworth.

SHEPPARD, P. M. 1951. A quantitative study of two populations of the moth Panaxia dominula (L.). Heredity, 5, 349-378.

SHEPPARD, P. M. AND COOK, L. M. 1962. The manifold effects of the medionigra gene of the moth Panaxia dominula and the maintenance of a polymorphism. Heredity, 17, 415-426. 